\title{
Hydrological processes in small catchments of mountain headwater lakes: The Tatra Mountains
}

\author{
Josef KřEČEK ${ }^{1}$, Jan Turek ${ }^{2}$, Eric LJungren ${ }^{3}$, Evžen Stuchlík ${ }^{4} \&$ Ferdinand ŠporkA $^{5}$ \\ ${ }^{1}$ Department of Hydrology, Faculty of Civil Engineering, Czech Technical University in Prague, Thákurova 7, CZ-16629 \\ Prague 6, Czech Republic; e-mail: krecek@cesnet.cz \\ ${ }^{2}$ Hydrobiological Institute, Academy of Sciences of the Czech Republic, Na Sádkách 7, CZ-37005 Ceské Budějovice, Czech \\ Republic \\ ${ }^{3}$ Department of Air and Water Science, Faculty of Earth Sciences, University of Uppsala, S-75236 Uppsala, Sweden \\ ${ }^{4}$ Hydrobiological Station, Institute for Environmental Studies, Charles University in Prague, P.O. Box 47, CZ-38801 Blatná, \\ Czech Republic \\ ${ }^{5}$ Department of Hydrobiology, Institute of Zoology, Slovak Academy of Sciences, Dúbravská cesta 9, SK-84506 Bratislava, \\ Slovakia
}

\begin{abstract}
This study evaluates runoff and different methods for the estimation of water balance and runoff genesis in four small alpine catchments, which lie outside the standard network of hydrological and climate networks. These test catchments, whose size ranges between 2.3 and 110 ha, are located above the timberline at elevations between 1,784 and 2,380 m. Their land surfaces consist of lakes, rock formations, debris deposits, and alpine meadows. Hydrological data were collected for the water year 2001. The catchments were instrumented by three automatic weather stations recording global and net solar radiation, air temperature, humidity, precipitation, and soil temperature. Lake water levels were registered with staff gauges and runoff evaluated from water storage calculations. Runoff genesis was investigated by means of chemical tracers (Rhodamine WT and Lithium chloride). Hydrological process estimations were made using standard methods including: the input of precipitation and snowmelt, both potential and actual evaporation, which was estimated by the approaches of HAmon, Priestley-TAYlor, Penman and Grindley, and runoff calculated from the lake storage, were compared with results of the conceptual hydrological BROOK90 model. The empirical results show that hydrological processes are governed by the temperature-dependent regime of high mountain snowmelt. However, the major differences in water yield and runoff genesis between watersheds were due to differences in the morphologies of the lakes and their basins, the soilvegetation complex, and runoff routing. Evaluating approaches to estimation, PENMAN's combination of both aerodynamic and energy balance method provides the best fit to observed data with observed evapotranspiration being 78 to $99 \%$ of the potential calculated. The deterministic BROOK90 model is effective for precipitation-runoff genesis studies in small headwater catchments. In the Ladové pleso basin predicted and observed water yield show close correlation. The annual sum of actual evapotranspiration calculated by BROOK90 $(352 \mathrm{~mm})$ corresponds closely to that estimated by the approach of Penman (386 mm).
\end{abstract}

Key words: Alpine catchments, precipitation, evaporation, runoff genesis, water balance, Slovakia, Poland.

\section{Introduction}

Alpine regions are supposed to represent the least disturbed environment in Europe. Generally, there is relatively low direct human impact. Alpine environments face several global impacts: atmospheric pollution, acid atmospheric deposition and climate change. In the last decade, EU funded projects (ALPE, MOLAR and EMERGE) have focussed, particularly, on geo-chemical and biological studies in remote alpine lakes (FoTT et al., 1994).

High altitude watersheds are critical for the recharge of water resources (the mountains are supposed to be water towers of the world), and alpine headwa- ter systems are strongly related to environmental security (HAIGH \& Ǩ̌EČEK, 2000). Water is the transport medium of solid particles, chemicals, and biota, so alpine lake environments are controlled by hydrological processes and interactions within lakes and their catchments. However, the landscape complexity typical of alpine catchments means that accurate empirical investigation demands a dense network of precipitation and stream gauging stations. Unfortunately, often, these distant mountain areas are considered marginal to national meteorological and hydrological networks and these kinds of investments in instrumentation and monitoring are unusual.

The aim of this paper is to contribute to the better 
Table 1. Morphology of studied basins.

\begin{tabular}{|c|c|c|c|c|c|c|c|}
\hline Basin & $\begin{array}{l}\text { Basin area } \\
\text { (ha) }\end{array}$ & $\begin{array}{l}\text { Lake area } \\
\text { (ha) }\end{array}$ & $\begin{array}{l}\text { Elevation range } \\
\quad(\mathrm{m} \text { a.s.l. })\end{array}$ & Prevailing face & $\begin{array}{c}\text { Land slope } \\
(\%)\end{array}$ & Basin order & $\begin{array}{c}\text { Shape index } \\
\mathrm{A} / \mathrm{L}^{2}\end{array}$ \\
\hline Starolesnianske pleso & 2.26 & 0.73 & $1986-2030$ & $\mathrm{NE}$ & 65 & 0 & 0.45 \\
\hline Ladové pleso & 13.80 & 1.72 & $2057-2350$ & $\mathrm{~S}$ & 69 & 1 & 0.34 \\
\hline Długi Staw Gąsienicowy & 64.84 & 1.59 & $1784-2301$ & $\mathrm{~N}$ & 62 & 2 & 0.63 \\
\hline Nižné Terianske pleso & 110.01 & 4.91 & $1941-2428$ & NW & 58 & 2 & 1.05 \\
\hline
\end{tabular}

Table 2. Land cover in watersheds.

\begin{tabular}{|c|c|c|c|c|c|c|c|c|}
\hline \multirow[t]{2}{*}{ Basin } & \multicolumn{2}{|c|}{ Lake } & \multicolumn{2}{|c|}{ Grassland } & \multicolumn{2}{|c|}{ Rock formations } & \multicolumn{2}{|c|}{ Debris cones } \\
\hline & (ha) & $(\%)$ & (ha) & $(\%)$ & (ha) & $(\%)$ & (ha) & $(\%)$ \\
\hline Starolesnianske pleso & 0.73 & 32 & 0.69 & 31 & 0.46 & 20 & 0.38 & 17 \\
\hline Ladové pleso & 1.72 & 13 & 3.60 & 26 & 3.04 & 22 & 5.44 & 39 \\
\hline Długi Staw Gąsienicowy & 1.59 & 2 & 12.65 & 20 & 37.95 & 58 & 12.65 & 20 \\
\hline Nižné Terianske pleso & 4.91 & 4 & 31.53 & 29 & 42.04 & 38 & 31.53 & 29 \\
\hline
\end{tabular}

Table 3. Water balance at the nearest stream gauging stations: mean annual values of precipitation $\left(P_{\mathrm{a}}\right)$, runoff $\left(R_{\mathrm{a}}\right)$ and evapotranspiration $\left(E T=P_{\mathrm{a}}-R_{\mathrm{a}}\right)$.

\begin{tabular}{llrrrr}
\hline Stream & Profile & Evidence number & $\begin{array}{c}\text { Basin area } \\
\left(\mathrm{km}^{2}\right)\end{array}$ & $\begin{array}{c}P_{\mathrm{a}} \\
(\mathrm{mm})\end{array}$ & $\begin{array}{c}R_{\mathrm{a}} \\
(\mathrm{mm})\end{array}$ \\
\hline Biely Váh & Nad Mlyničnou vodou & $4-21-01-030$ & 34.8 & 891 & 571 \\
Poprad & Nad Malým Popradom & $3-01-02-013$ & 320 & 865 \\
Biela Voda & Nad Javorinkou & $3-01-01-001$ & 48.3 & 1285 \\
\hline
\end{tabular}

understanding hydrological processes in the high altitude catchments of the High Tatra Mountains (Mts). Since 2000, water balance and runoff genesis have been studied in four previously un-gauged headwater catchments which lie outside the standard hydrological network.

\section{Material and methods}

\section{The research site}

Four investigated catchments are located in the High Tatra Mts forming the highest massif in the Carpathians. The basins of lakes Ladové pleso, Nižné Terianske pleso, and Starolesnianske pleso are situated in Slovakia, and the basin of the lake Długi Staw Gạsienicowy in Poland. The latitude of catchments varies from 49.17 to $49.22 \mathrm{~N}$, longitude from 20.01 to 20.17 E, elevation from 1784 to $2380 \mathrm{~m}$ a.s.l., and catchment area between 2.3 and 110 ha (Tab. 1).

The geology is formed by crystalline bedrock with shallow podsolic soils (depth varies from 0.2 to $0.6 \mathrm{~m}$ ) with high content of stones. All those watersheds are located above the timberline. The land surface consists of lakes, alpine meadows, rock formations and debris cones (Tab. 2). The percentage of alpine meadows in watersheds varies from 20 to $31 \%$ of the watershed area. The vegetation is represented by dry tundra with dominant species of Calamagrostis villosa, Festuca picta, and Luzula luzuloides) with patches of dwarf pine (Pinus mugo). The percentage of rock (bare or covered with lichens, particularly, Rhizocarpon, Acarospora oxytona, and Dermatocarpon luridum) increases with the elevation. Grazing or other land-use activities have been prohibited since the early 1950s, when the National Park of the Tatra Mts was proclaimed.

The investigated area can be characterised by the climate type 'Dfc' of the Köppen classification system (HENDERSON-SEllers \& Robinson, 1989). In the region of the High Tatra Mts, LAJCZAK (1996) reports negative gradient of mean annual air temperature of $-0.6^{\circ} \mathrm{C}$ and positive gradient of the mean annual precipitation of $50 \mathrm{~mm}$ per $100 \mathrm{~m}$ of elevation, respectively. Thus, the estimates of mean annual air temperature over the investigated area might vary from -2.6 to $1.6^{\circ} \mathrm{C}$, and precipitation from 1200 to 1550 $\mathrm{mm}$. However, precipitation sums are generally higher in the northern part of the mountains, and some valley can reach more than $2000 \mathrm{~mm}$ per year. TOMLAIN (1985) reported the range of mean annual evapotranspiration in the High Tatra Mts from 250 to $300 \mathrm{~mm}$ by the negative gradient of -18 $\mathrm{mm}$ per $100 \mathrm{~m}$ of elevation.

The basins of lakes Długi Staw Gạsienicowy, Ladové pleso and Starolesnianske pleso belong to headwaters of the Visla River, the basin of the Nižné Terianske pleso is drained by the Váh River. In all, the drainage channel network is poorly developed. The basins of Długi Staw Gassienicowy, Nižné Terianske pleso and Starolesnianske pleso are drained by both seepage and complicated stream channel system, while the basin of Ladové pleso is drained only by the lake seepage.

Historically, the standard network of precipitation and stream gauging stations in the High Tatras has been focussed on watersheds larger than $40 \mathrm{~km}^{2}$ (HMU, 1968). Therefore, the research sites are included only in the hydrological analyses of larger watersheds (Tab. 3). Extrapolating the water balance into smaller areas, thus, in elevations of 
Table 4. Parameters observed at the automatic weather stations.

\begin{tabular}{|c|c|c|c|c|c|c|}
\hline \multirow{2}{*}{$\begin{array}{l}\text { Watershed } \\
\text { Weather Station } \\
\text { Parameter }\end{array}$} & \multicolumn{2}{|c|}{$\begin{array}{l}\text { L'adové pleso } \\
\text { NOEL } 2000\end{array}$} & \multicolumn{2}{|c|}{$\begin{array}{c}\text { Długi Staw Gąsienicowy } \\
\text { NOEL } 2000\end{array}$} & \multicolumn{2}{|c|}{$\begin{array}{c}\text { Nižné Terianske pleso } \\
\text { DELTA-T-LOGGER }\end{array}$} \\
\hline & Height (m) & Interval (h) & Height (m) & Interval (h) & Height (m) & Interval $(\mathrm{h})$ \\
\hline Global radiation & 5 & 0.5 & 5 & 0.5 & 5.0 & 0.5 \\
\hline Reflected radiation & - & - & - & - & 5.0 & 0.5 \\
\hline Net radiation & - & - & - & - & 5.0 & 0.5 \\
\hline Air temperature & 5 & 0.5 & 5 & 0.5 & 3.5 & 0.5 \\
\hline Humidity & 5 & 0.5 & 5 & 0.5 & 3.5 & 0.5 \\
\hline Air pressure & - & 1.0 & - & 1.0 & 3.5 & 1.0 \\
\hline Wind speed & 10 & 0.5 & 10 & 0.5 & 5.0 & 0.5 \\
\hline Wind direction & 10 & 0.5 & 10 & 0.5 & 5.0 & 0.5 \\
\hline Soil temperature & -0.02 & 0.5 & -0.02 & 0.5 & -0.02 & 0.5 \\
\hline Precipitation & 4.5 & 0.5 & - & - & 2.0 & 24.0 \\
\hline Water level & - & 0.5 & - & 0.5 & - & 1.0 \\
\hline
\end{tabular}

1,800-2,000 $\mathrm{m}$, the mean annual values of precipitation $\left(P_{\mathrm{a}}\right)$ and evapotranspiration $(E T)$ are characterised by the range of $P_{\mathrm{a}}=1800-2000 \mathrm{~mm}$, and $E T=150-200 \mathrm{~mm}$ (DUB \& NĚMEC, 1969). Later, for smaller basin of the Studený potok brook (profile Nad Tatranskou Lesnou, basin number: 3-01-02-056, area of $18.5 \mathrm{~km}^{2}$ ), VOLOŠČUK et al. (1994) reported the runoff coefficient $k_{\mathrm{o}}=0.92$ by the annual evapotransipration $E T=150 \mathrm{~mm}$.

\section{Instrumentation}

Investigated catchments were instrumented in the year of 2000 , and the detailed observation was carried out in the hydrological year of 2001 (1 October 2000 - 30 September 2001). Three automatic weather stations were installed in the neighbourhood of the lakes Ladové pleso, Długi Staw Ga̧sienicowy (NOEL 2000) and Nižné Terianske pleso (DELTA-T-LOGGER) in the elevation between 1,784 and $2,057 \mathrm{~m}$ a.s.l. Parameters of global radiation, air temperature and humidity, air pressure, soil temperature, wind speed and direction, rainfall (tipping-bucket recorder, 200 $\mathrm{cm}^{2}$ ) and water level at the lakes were registered in 0.5, 1.0 or 24 hour intervals (Tab. 4). The reflected and net radiation was observed only at the Nižné Terianske pleso. All the observed meteorological parameters represent near the ground climate above the grass-rock formations. Meteorological data (including net radiation above grassland) of the nearest standard weather station of Skalnaté pleso (elevation of $1,762 \mathrm{~m}$ ) were also provided.

Additional 8 storage rain gauges $\left(315 \mathrm{~cm}^{2}\right)$ were installed in the studied catchments to be collected weekly in the summer and monthly during the winter. The rain gauges exposed in the field were not provided with windshields. In the watersheds, the snow-pack (depth, density and water equivalent of snow) was observed in $20 \mathrm{~m}$ intervals following the snowlines (from 1 to 3 ) across the basin area.

The water level in the lakes was registered by stages (vertical staff gauge) and pressure gauges registered at the automatic weather stations. For each lake, the volume-depth (bathymetric) curve was plotted, and, than, the volume increment per time estimated (LJUNGGREN, 2002).

The registration of catchment outflows by traditional stream-flow gauging is almost impossible because of complicated morphology and not fully developed stream channels. Therefore, tracers were applied to investigate the genesis and pathways of runoff in those small headwater basins. Tracers of Rhodamin WT and Lithium chloride $(\mathrm{LiCl})$ were applied into the lakes of Ladové pleso (24 October 2000 and 19 July 2001) and Starolesnianske pleso (24 October 2000). The tracers were applied from the boat over the water surface. After the application, concentrations of both tracers in the lakes were monitored (depth of $0,3,8,13 \mathrm{~m}$ under the water level, and $0.5 \mathrm{~m}$ above the bottom) in daily, weekly and later in two-week intervals.

\section{Data processing}

Precipitation

Precipitation sums in hourly, daily and monthly intervals were evaluated by the hypsometric method - an extrapolation of the observation network with elevation (SHAW, 1991). The gauges exposed in the field were not provided with windshields. Therefore, the wind error was compensated by coefficients $k_{\mathrm{r}}=1.16$ (collected rain), and $k_{\mathrm{s}}=$ 1.65 (collected snow) according to the wind speed observed in the range of 2-4 $\left(\mathrm{m} \mathrm{s}^{-1}\right)$ (LINSLEY et al., 1975).

Possible additional forms of precipitation (dew, occult fog-drip, cloud interception etc.) were not studied in the investigated catchments. In the year of 1998, STRUNECKY (1988, in LOPATOVÁ, 2003) reported the annual sum of additional occult precipitation by only 25 ( $\mathrm{mm} /$ year) for grassland (mean grass height of $0.30 \mathrm{~m}$ ) in the neighbouring basin of the Skalnaté pleso. Later, LopATOVÁ (2003) found only 39 days with a significant fog-drip at the standard weather station "Skalnaté pleso" (1,766 m a.s.l.) during the last four years. From the above results we can consider the additional sum of precipitation in the year of $2000 / 2001$ by an approximate range of $20-30 \mathrm{~mm}$.

\section{Evapotranspiration}

In the vegetation period, the estimates of potential evapotranspiration ( $E P, \mathrm{~mm}$ per a unit of time) were calculated by empirical formulae of HAMON (temperature-based, $E$ $H A M)$, Priestley-TAYlor (radiation-based, E-PRT) and PENMAN (combination of both aerodynamic and energy balance method, E-PEN) described in CHOW et al. (1988) and SHAW (1991):

$$
\begin{aligned}
& E P-H A M=2.98 N e_{\mathrm{d}} /\left(T_{\mathrm{a}}+273.3\right) \\
& E P-P R T=1.3 \Delta /(\Delta+\gamma) H_{\mathrm{T}} \\
& E P-P E N=\frac{(\Delta / \gamma) H_{\mathrm{T}}+E_{\mathrm{at}}}{(\Delta / \gamma)+1}
\end{aligned}
$$


where, $N$ - maximum possible daily sunshine (hours/day), $T_{\mathrm{a}}-$ mean daily air temperature $\left({ }^{\circ} \mathrm{C}\right), e_{\mathrm{a}}$ - vapour pressure in the atmosphere $(\mathrm{mm}), e_{\mathrm{d}}$ - saturated vapour pressure $(\mathrm{mm}), \Delta$ - slope of 'saturated vapour pressure - air temperature' curve $\left(\mathrm{mm} /{ }^{\circ} \mathrm{C}\right), \gamma-$ psychrometric constant $\left(\mathrm{mm} /{ }^{\circ} \mathrm{C}\right), u_{2}$ - wind speed at $2 \mathrm{~m}$ above the vaporizing surface $\left(\mathrm{m} \mathrm{s}^{-1}\right), H_{\mathrm{T}}$ - evaporation equivalent of net radiation $(\mathrm{mm}), E_{\text {at }}-$ evaporation equivalent of aerodynamic conditions $(\mathrm{mm})$ expressed by equation

$$
E_{\text {at }}=0.35\left(1+u_{2} / u_{2} 100\right)\left(e_{\mathrm{a}}-e_{\mathrm{d}}\right)
$$

The evaporation equivalent $H_{\mathrm{T}}$ can be exactly evaluated from net radiation $R_{\mathrm{n}}\left(\mathrm{W} \mathrm{m} \mathrm{m}^{-2}\right)$, measured at weather station of the Nižné Terianske pleso (or at the standard weather station "Skalnaté pleso"), and latent heat of vaporization $L_{\mathrm{v}}$ $\left(\mathrm{J} \mathrm{kg}^{-1}\right)$ by the equation (5).

$$
H_{\mathrm{T}}=R_{\mathrm{n}} / L_{\mathrm{v}}
$$

In research sites of Ladové pleso and Długi Staw Gạsienicowy, the evaporation equivalent $\left(H_{\mathrm{T}}\right)$ was calculated by simplification (6):

$$
H_{\mathrm{T}}=(1-\alpha) G / L_{\mathrm{v}}
$$

where, $G$ - global radiation $\left(\mathrm{W} \mathrm{m}^{-2}\right), L_{\mathrm{v}}$ - latent heat of vaporization $\left(\mathrm{J} \mathrm{kg}^{-1}\right)$, and $\alpha$ - albedo $(-)$. Values reported by Burroughs (1991) were used for albedo: $\alpha=0.1$ (water), $\alpha=0.25$ (grassland), $\alpha=0.3$ (rock or debris cones), and $\alpha=0.95$ (snow).

In the absence of observed radiation parameters, PENMAN (SHAW, 1991) recommends empirical equations to calculate the evaporation equivalent of net radiation $H_{\mathrm{T}}(\mathrm{mm})$ in daily intervals:

$$
\begin{aligned}
& H_{\mathrm{T}}=R_{\mathrm{i}}-R_{\mathrm{o}} \\
& R_{\mathrm{i}}=R_{\mathrm{a}}(1-\alpha)(0.16+0.62 n / N) \\
& R_{\mathrm{o}}=\sigma T_{\mathrm{a}}\left(0.47-0.075 e_{\mathrm{d}}^{0.5}\right)(0.17+0.83 n / N)
\end{aligned}
$$

where, $R_{\mathrm{i}}$ - vaporizing equivalent of incoming and $R_{\mathrm{o}}-$ outcoming radiation of the vaporizing surface $(\mathrm{mm}), R_{\mathrm{a}}-$ vaporizing potential to the latitude and season $(\mathrm{mm}), \sigma-$ Sefan-Boltzman constant $\left(5.67 \times 10^{-8} \mathrm{~W} \mathrm{~m}^{-2} \mathrm{~K}^{-4}\right), n-$ actual daily sunshine (hours day ${ }^{-1}$ ), and $N$ - maximum possible daily sunshine (hours day ${ }^{-1}$ ).

The radiation income into terrestrial parts of a basin was calculated from the radiation income into the horizontal surface (data measured by sensors or calculated by equations $7,8,9$ ) and the mean slope and face (HENDERSONSELlERs \& ROBINSON, 1989).

Generally, in mountain areas in summer, temperature inversions are rare and the ambient temperature decreases approximately linearly with altitude (BURROUGHS, 1991). Therefore, the linear decrease of the air temperature of $1.4^{\circ} \mathrm{C}$ per $100 \mathrm{~m}$ (reported by SPORKA et al., 2006) was accepted in the temperature-based approach (equation 1).

Considering the water surface of lakes, the vaporizing potential ( $E P$, equations 1-4) corresponds to the actual evaporation $(E T)$. In the case of grassland, the actual evapotranspiration $(E T)$ was calculated by the method of GRINDLEY (SHAW, 1991) balancing the potential evapotranspiration $(E P)$ and soil moisture deficit $(S M D)$ given

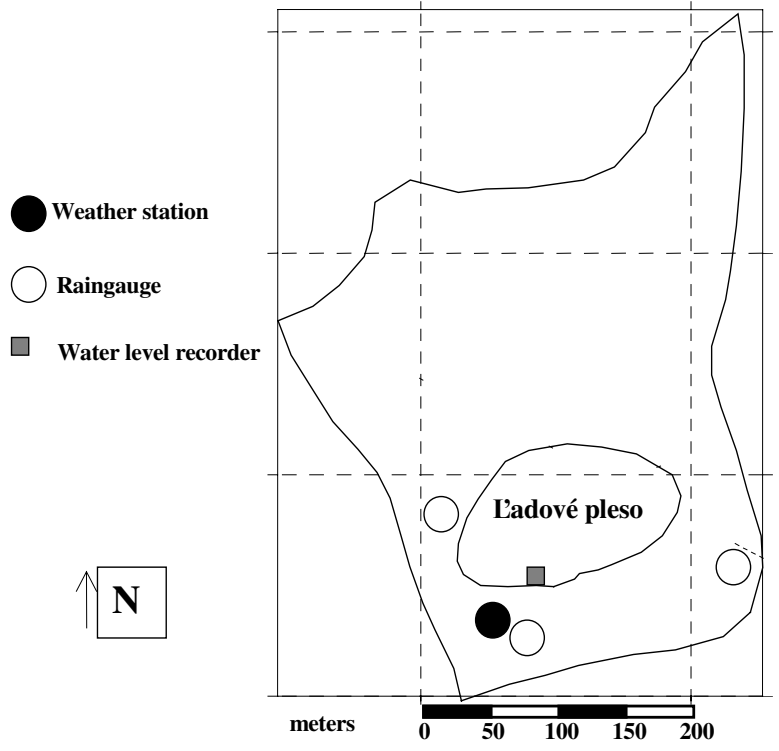

Fig. 1. Instrumented catchment of Ladové pleso.

as the difference of vaporizing potential $(E P)$, precipitation $(P)$ and root constant $(R C)$

$$
S M D=E P-P+R C
$$

since the beginning of the vegetation period. The root constant of the presented grassland (shallow alpine soils) was assumed as $R C=15 \mathrm{~mm}$.

The vaporization from the surface of rock formations or debris cones includes namely the process of surface interception ( $E-I N T, \mathrm{~mm}$ per a unit of time), Kॅ̆EČEK \& RUSNOK (1993). Considering daily time steps, the model of daily interception loss (HALL et al., 1992) can be accepted

$$
E-I N T=\beta\left(1-\exp \left(-\delta P_{\mathrm{d}}\right)\right.
$$

where, $P_{\mathrm{d}}$ - daily rain $(\mathrm{mm}), \beta$ and $\delta$-empirical parameters (recommended: $\beta=1.2 \mathrm{~mm}$, and $\delta=0.7 \mathrm{~mm}^{-1}$ ).

In the period of air temperatures below zero, KEMEL (1972) reported a simple temperature-based approach from $E T=1\left(\mathrm{~mm} \mathrm{day}^{-1}\right)$ by $T_{\mathrm{a}}=\left(0^{\circ} \mathrm{C}\right)$ to $E T=0.1\left(\mathrm{~mm} \mathrm{day}^{-1}\right)$ by $T_{\mathrm{a}}=-20\left({ }^{\circ} \mathrm{C}\right)$. Monthly values of $E T(\mathrm{~mm})$ versus air temperature $T\left({ }^{\circ} \mathrm{C}\right)$ were approximated by the polynomial equation of second order (Fig. 4):

$$
E T=30+3.1 T+0.09 T^{2}
$$

Runoff

The residence time in lakes corresponds to the inflowoutflow relationship. Changes in tracer concentrations of the lake water $M_{\mathrm{t}}\left(\mathrm{kg} \mathrm{m}^{-3}\right)$ with the time $t$ (days) can be expressed by equation (12), COLE \& PACE (1998, in TUREK, 2002):

$$
M_{\mathrm{t}}=M_{\mathrm{o}} \mathrm{e}^{-k}
$$

where, $M_{\mathrm{o}}$ - initial tracer concentration at the application $\left(\mathrm{kg} \mathrm{m}^{-3}\right)$, and $k$-dilution rate $\left(\right.$ day $\left.^{-1}\right)$. Thus, the residence time $\tau$ (days) can be expressed by equation (13): 


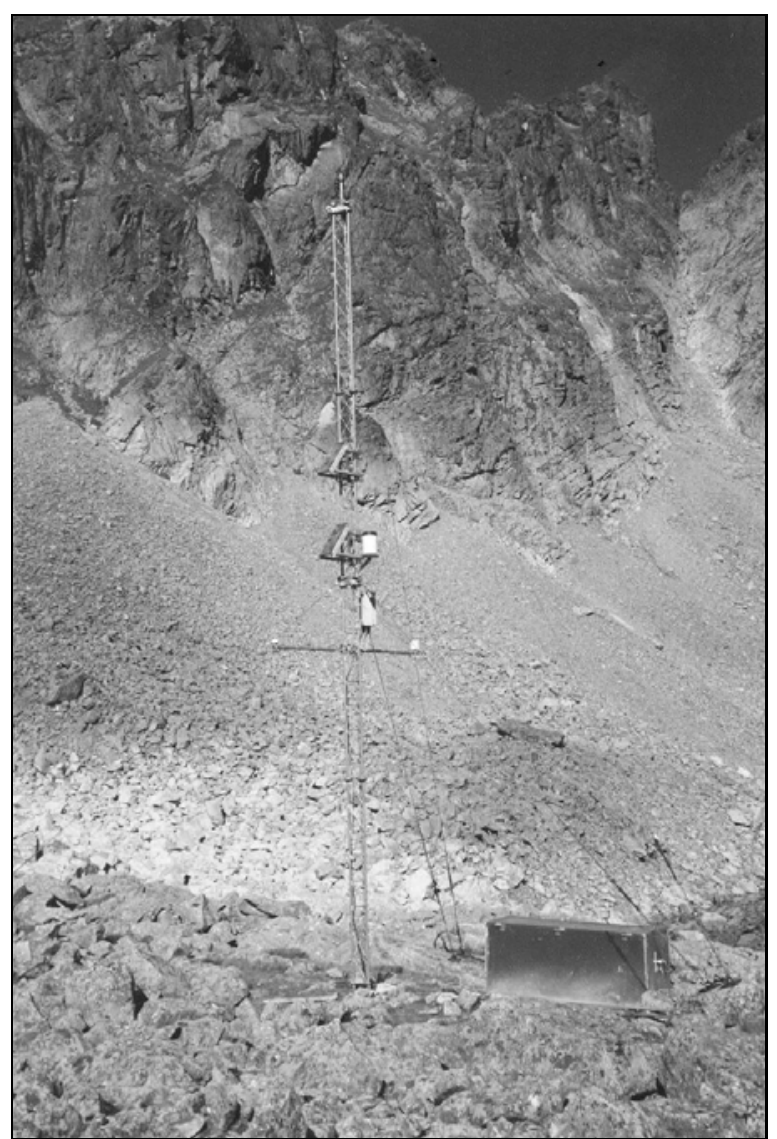

Fig. 2. Automatic weather station near Ladové pleso (photo: J. Křeček, 2001).

$$
\tau=1 / k=\left(\ln M_{\mathrm{o}}-\ln M_{\mathrm{t}}\right) / t
$$

The morphology of the Ladové pleso basin (Fig. 1) indicates drainage of the catchment mainly by processes of lake seepage. Therefore, this catchment seems to be suitable for verification of a precipitation-runoff model. Water yield from the Ladové pleso basin was calculated from the water balance model of Ladové pleso by LJUNGGREN (2002). Here, outflow from the catchment is supposed to proceed by the seepage from the lake, which is related to the water level in the lake and season.

The deterministic model BROOK90 (FEDERER, 1992) was applied to simulate precipitation-runoff genesis at the Ladové pleso basin in daily time steps. BROOK90 is a lumped parameter hydrological model operating in daily or hourly intervals. The model simulates land phases of precipitation, evapotranspiration and stream-flow of a small uniform watershed. Water is stored in the model either as intercepted rain or snow, snow on the ground, soil water, and groundwater. Water outputs are evaporation, deep seepage and stream flow. Stream flow is generated at the same time interval as precipitation input. Water is stored in the model either as intercepted rain or snow, snow on the ground, soil water in two layers and groundwater. The approach of PENMAN-MONTEITH (equation 3 modified by both atmospheric and canopy resistance) is used to calculate the evaporation potential. The actual evapotranspiration consists of five components: evaporation of intercepted

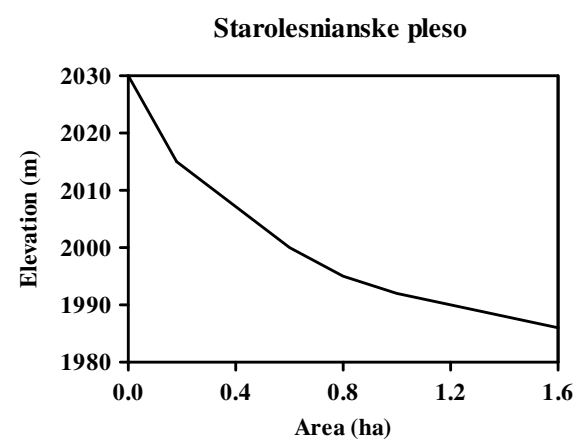

L'adové pleso

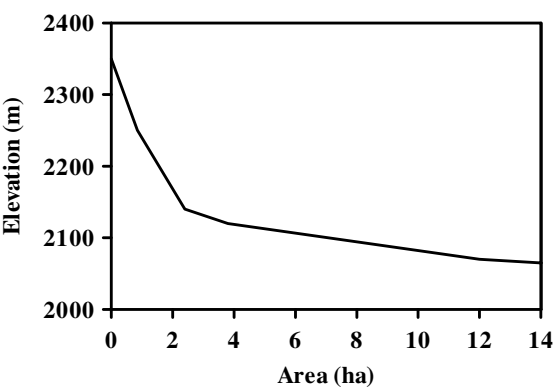

Długi Staw Gąsienicowy

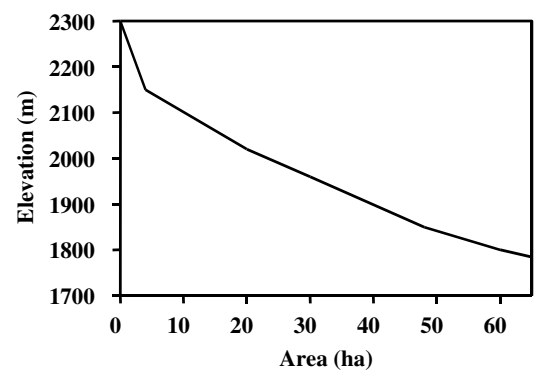

Nižné Terianske pleso

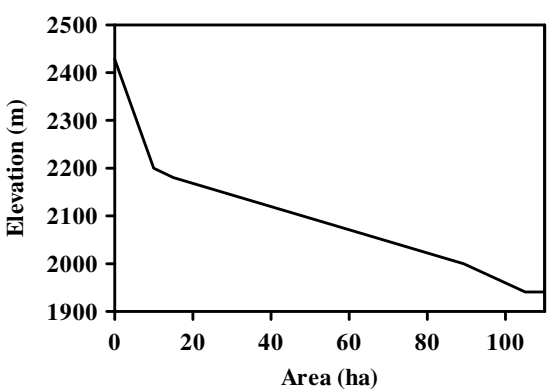

Fig. 3. Hypsometric curves of studied basins.

rain and snow, evaporation of snow, soil evaporation from the top soil layer and transpiration from soil layers containing roots. The model takes into consideration the degree of the slope, which is important for the evaporation and the water movement in the soil and surface. The canopy is characterised by maximum leaf area index LAI $=3.2$ in the high summer, albedo $\alpha=0.25$. Three soil layers were considered representing the alpine meadow: $\mathrm{A}$ - horizon (depth of $0.14 \mathrm{~m}$, stone volume fraction of 0.2 ), B - horizon (depth of $0.33 \mathrm{~m}$, stone volume fraction of 0.3 ), C - horizon (depth of $0.45 \mathrm{~m}$, stone volume fraction 0.7 ). The matrix porosity 
Table 5. Monthly sums of aerial precipitation over the investigated basins, 2000-2001.

\begin{tabular}{|c|c|c|c|c|c|}
\hline Month & $\begin{array}{l}\text { Starolesnianske } \\
\text { pleso }\end{array}$ & $\begin{array}{l}\text { Ladové } \\
\text { pleso }\end{array}$ & $\begin{array}{l}\text { Długi Staw } \\
\text { Gąsienicowy }\end{array}$ & $\begin{array}{c}\text { Nižné Terianske } \\
\text { pleso }\end{array}$ & $\begin{array}{l}\text { Climate normal } \\
\quad(1931-1960)\end{array}$ \\
\hline $\mathrm{X}$ & 85 & 87 & 92 & 106 & 115 \\
\hline XI & 98 & 123 & 102 & 131 & 110 \\
\hline XII & 51 & 61 & 53 & 74 & 105 \\
\hline I & 46 & 78 & 67 & 86 & 105 \\
\hline II & 30 & 41 & 21 & 43 & 90 \\
\hline III & 21 & 78 & 85 & 53 & 95 \\
\hline IV & 125 & 135 & 152 & 45 & 125 \\
\hline $\mathrm{V}$ & 127 & 139 & 120 & 77 & 165 \\
\hline VI & 465 & 423 & 529 & 329 & 215 \\
\hline VII & 416 & 407 & 459 & 380 & 225 \\
\hline VIII & 139 & 173 & 230 & 189 & 225 \\
\hline IX & 248 & 269 & 302 & 81 & 170 \\
\hline SUM & 1851 & 2014 & 2212 & 1594 & 1745 \\
\hline
\end{tabular}

Table 6. Monthly air temperature observed at instrumented weather stations, 2000-2001.

\begin{tabular}{|c|c|c|c|c|}
\hline Month & $\begin{array}{l}\text { L'adové pleso } \\
\qquad(2066 \mathrm{~m})\end{array}$ & $\begin{array}{l}\text { Długi Staw Gassienicowy } \\
(1791 \mathrm{~m})\end{array}$ & $\begin{array}{c}\text { Nižné Terianske pleso } \\
(1948 \mathrm{~m})\end{array}$ & $\begin{array}{l}\text { Climate normal (1931-1960) } \\
(2000 \mathrm{~m})\end{array}$ \\
\hline $\mathrm{X}$ & 5.5 & 7.3 & 5.7 & 2.0 \\
\hline XI & 0.2 & 2.1 & 0.4 & -2.0 \\
\hline XII & -3.1 & -3.8 & -3.6 & -5.0 \\
\hline $\mathrm{I}$ & -5.9 & -5.1 & -6.0 & -8.0 \\
\hline II & -9.6 & -4.7 & -7.1 & -3.0 \\
\hline III & -3.1 & 0.0 & -3.2 & -2.0 \\
\hline IV & -1.8 & -0.1 & -0.9 & 0.0 \\
\hline $\mathrm{V}$ & 3.3 & 5.4 & 4.0 & 6.0 \\
\hline VI & 3.6 & 5.6 & 4.8 & 8.0 \\
\hline VII & 8.7 & 10.7 & 9.6 & 10.0 \\
\hline VIII & 9.7 & 11.3 & 10.1 & 10.0 \\
\hline IX & 2.8 & 3.9 & 3.1 & 6.0 \\
\hline Mean & 1.6 & 2.9 & 1.5 & 1.7 \\
\hline
\end{tabular}

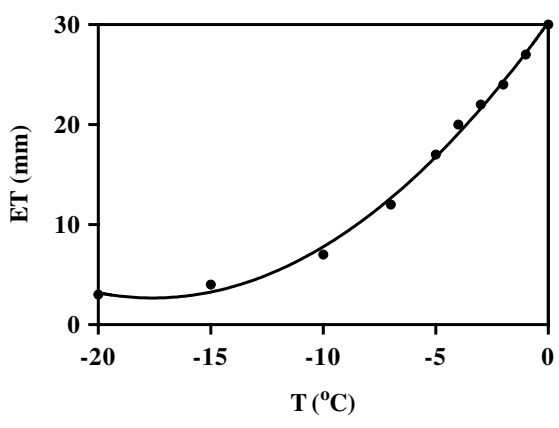

Fig. 4. Monthly evaporation ET ( $\mathrm{mm})$ from the snow-pack related to the mean monthly air temperature $\mathrm{T}\left({ }^{\circ} \mathrm{C}\right)$ in the range from 0 to $-20\left({ }^{\circ} \mathrm{C}\right): E T=30+3.1 T+0.09 T^{2}$.

0.45 and water potential at field capacity $-12(\mathrm{kPa})($ sandy loam soil) are assumed. The fine root mass is considered by $400\left(\mathrm{~g} \mathrm{~m}^{-2}\right)$ to calculate the rhizosphere resistance. In the rock formations and debris cones, a crashed rock of surface area index of $\mathrm{SAI}=1.6$ and $\mathrm{SAI}=2.5$ uniformly distributed is assumed. The evaporation from the rock and debris cones is supposed to be formed only by the surface interception. In the winter, the evaporation from a smooth snow cover over the watershed area is supposed following the vaporiz- ing potential. The degree-day snowmelt factor is assumed by value of $4.5\left(\mathrm{~mm} \mathrm{day}^{-1}{ }^{\circ} \mathrm{C}^{-1}\right)$.

\section{Results and discussion}

\section{Precipitation}

Mean monthly and annual sums of aerial precipitation of studied catchments in the hydrologic year of 2001 are compared with the data of climate normal 19311960 (HMU, 1962) extrapolated to the focussed area (Tab. 5). In comparison to the climate normal (19611990), the estimates of annual precipitation differ from -9 to $27 \%$. Particularly low winter precipitation of 2001 is evident; precipitation in the period XII-III is only 8 $12 \%$ of the annual sum versus $22 \%$ of the normal.

From a relatively low number of observed foggy days in the weather station of Skalnaté pleso (39 events during four years, LopATOVÁ, 2003) it is possible to consider in studied basins the additional sum of occult precipitation in the year of $2000 / 2001$ by the range of 20-30 mm (1-2\% of annual precipitation). However, in this region, HMU (1962) reported 100 foggy days per year of the climate normal 1931-1960. Worldwide, high values of cloud interception ( $10 \%$ of annual precipita- 
Table 7. Monthly estimates of PENMAN's potential evaporation calculated in hourly $\left(P E-P E N_{(\mathrm{h})}\right)$, daily $\left(P E-P E N_{(\mathrm{d})}\right)$ and monthly $\left(P E-P E N_{(\mathrm{m})}\right)$ intervals, grassland near the lake of L'adové pleso, 2000-2001.

\begin{tabular}{cccc}
\hline Month & $\begin{array}{c}P E-P E N_{(\mathrm{h})} \\
(\mathrm{mm})\end{array}$ & $\begin{array}{c}P E-P E N_{(\mathrm{d})} \\
(\mathrm{mm})\end{array}$ & $\begin{array}{c}P E-P E N_{(\mathrm{m})} \\
(\mathrm{mm})\end{array}$ \\
\hline X & 46.6 & 44.9 & 37.5 \\
XI & 14.4 & 14.6 & 36.3 \\
XII & 18.2 & 18.8 & 0.0 \\
I & 7.4 & 7.9 & 0.0 \\
II & 9.7 & 9.4 & 0.0 \\
III & 21.1 & 21.1 & 0.0 \\
IV & 25.7 & 22.1 & 0.0 \\
V & 60.7 & 59.3 & 61.0 \\
VI & 44.5 & 43.5 & 59.0 \\
VII & 50.5 & 49.0 & 32.6 \\
VIII & 59.9 & 59.2 & 64.7 \\
IX & 26.6 & 25.7 & 62.6 \\
SUM & 385.3 & 375.5 & 353.7 \\
\hline
\end{tabular}

tion) in alpine catchments are considered (GONZALES, 2000) particularly in forest stands. Kॅ̌EČEK \& RUSNOK (1993) reported a significant role of occult precipitation in the process of interception at debris cones in the Zagros Mountains (Iran). Therefore, the considered values of additional precipitation forms in studied basins (20-30 mm per year) might underestimate the real situation.

\section{Evapotranspiration}

Monthly air temperatures registered at the instrumented weather stations well correspond with the climate normal of 1931-1960 (Tab. 6).

At the weather station of Ladové pleso (grass-rock, elevation of $2066 \mathrm{~m}$ ), monthly and annual (2000-2001) estimates of PENMAN's potential evaporation calcu- lated in hourly $\left(P E-P E N_{(\mathrm{h})}\right)$, daily $\left(P E-P E N_{(\mathrm{d})}\right)$ and monthly $\left(P E-P E N_{(\mathrm{m})}\right)$ intervals are given in Table 7 . Annual values $\left(P E-P E N_{(\mathrm{h})}=385 \mathrm{~mm}, P E-P E N_{(\mathrm{d})}=\right.$ $376 \mathrm{~mm}$ and $P E-P E N_{(\mathrm{m})}=354 \mathrm{~mm}$ ) differ in $9 \mathrm{~mm}$ ( $2 \%$, hourly versus daily steps) and $31 \mathrm{~mm}$ ( $8 \%$, hourly versus monthly steps), respectively. Monthly values differ from 0 to $3.6 \mathrm{~mm}$ (0-9\%, hourly versus daily steps), and from 0 to $25 \mathrm{~mm}$ (3-100\%, hourly versus monthly steps), respectively. The $P E$-estimates of hourly and daily steps show relatively good agreement in both monthly and annual data, monthly $P E$-values underestimate the vaporizing potential particularly in the winter period $(110 \mathrm{~mm}$ in the period of XII-IV). The annual estimate of evaporation from the snow-pack by the simple empirical approach (equation 12) in the winter period XII-IV is $78 \mathrm{~mm}$ (Tab. 8 ), $29 \%$ lower in comparison with $P E-P E N_{(\mathrm{h})}$.

Comparing the annual estimates of $P E-P E N$ with potential evapotranspiration calculated at the nearest neighbouring standard weather station "Skalnaté pleso" (grassland, elevation of $1762 \mathrm{~m}, P E-P E N_{(\mathrm{h})}=$ $494 \mathrm{~mm}$, and $P E-P E N_{(\mathrm{d})}=474 \mathrm{~mm}$, LJUNGGREN, 2002), a negative gradient of $-30 \mathrm{~mm}$ per $100 \mathrm{~m}$ of elevation is evident. Anyway, this gradient is not possible generalize because of complicated mountain morphology at the research area.

Annual estimates of vaporizing potential from water surface in studied catchments vary according to the formula applied: $E-H A M=232-261 \mathrm{~mm}$ (temperaturebased equation of HAMON), E-PRT $=350-423 \mathrm{~mm}$ (radiation-based equation of PRIESTLEY-TAYLOR), and $E-P E N=401-537 \mathrm{~mm}$ (combination equation of PENMAN). The approach of PRIESTLEY-TAYLOR (equation 2) considers the aerodynamic part of vaporization by constant $30 \%$ of the total evaporation loss. The Penman's combination of both aerodynamic and energy balance method seems to provide the most realistic fit

Table 8. Evaporation from snow-pack, 2000-2001.

\begin{tabular}{ccccc}
\hline Month & Starolesnianske pleso & Ladové pleso & Długi Staw Gąsienicowy & Nižné Terianske pleso \\
\hline XII & 18 & 18 & 18 & 14 \\
I & 13 & 13 & 10 & 22 \\
II & 8 & 7 & 24 & 12 \\
III & 20 & 18 & 88 & 27 \\
IV & 26 & 22 & 78 & 97 \\
\hline
\end{tabular}

Table 9. Estimates of potential annual evapotranspiration in studied watersheds, 1.10.2000 - 30.9.2001.

\begin{tabular}{lcccc}
\hline Watershed & $\begin{array}{c}P E-H A M \\
\left(\mathrm{~mm} \mathrm{year}^{-1}\right)\end{array}$ & $\begin{array}{c}P E-P R T \\
\left(\mathrm{~mm} \mathrm{year}^{-1}\right)\end{array}$ & $\begin{array}{c}P E-P E N \text { water } \\
\left(\mathrm{mm} \mathrm{year}^{-1}\right)\end{array}$ & $\begin{array}{c}P E-P E N \text { grass } \\
\left(\mathrm{mm} \mathrm{year}^{-1}\right)\end{array}$ \\
\hline Starolesnianske pleso & 246 & 423 & 436 & 354 \\
Ladové pleso & 232 & 410 & 428 & 342 \\
Długi Staw Gassienicowy & 260 & 350 & 401 & 316 \\
Nižné Terianske pleso & 261 & 391 & 537 & 302 \\
\hline
\end{tabular}


Table 10. Actual annual evapotranspiration $\left(\mathrm{mm} \mathrm{year}^{-1}\right)$ from studied watersheds, 1.10.2000 - 30.9.2001.

\begin{tabular}{lcccc}
\hline Period & Starolesnianske pleso & L'adové pleso & Dlugi Staw Gąsienicowy & Nižné Terianske pleso \\
\hline XII-IV & 85 & 78 & 88 & 97 \\
V-XI & 326 & 308 & 309 & 326 \\
Annual & 411 & 386 & 397 & 423 \\
\hline
\end{tabular}

\section{Ladové Pleso: 1.10.2000-30.9.2001}

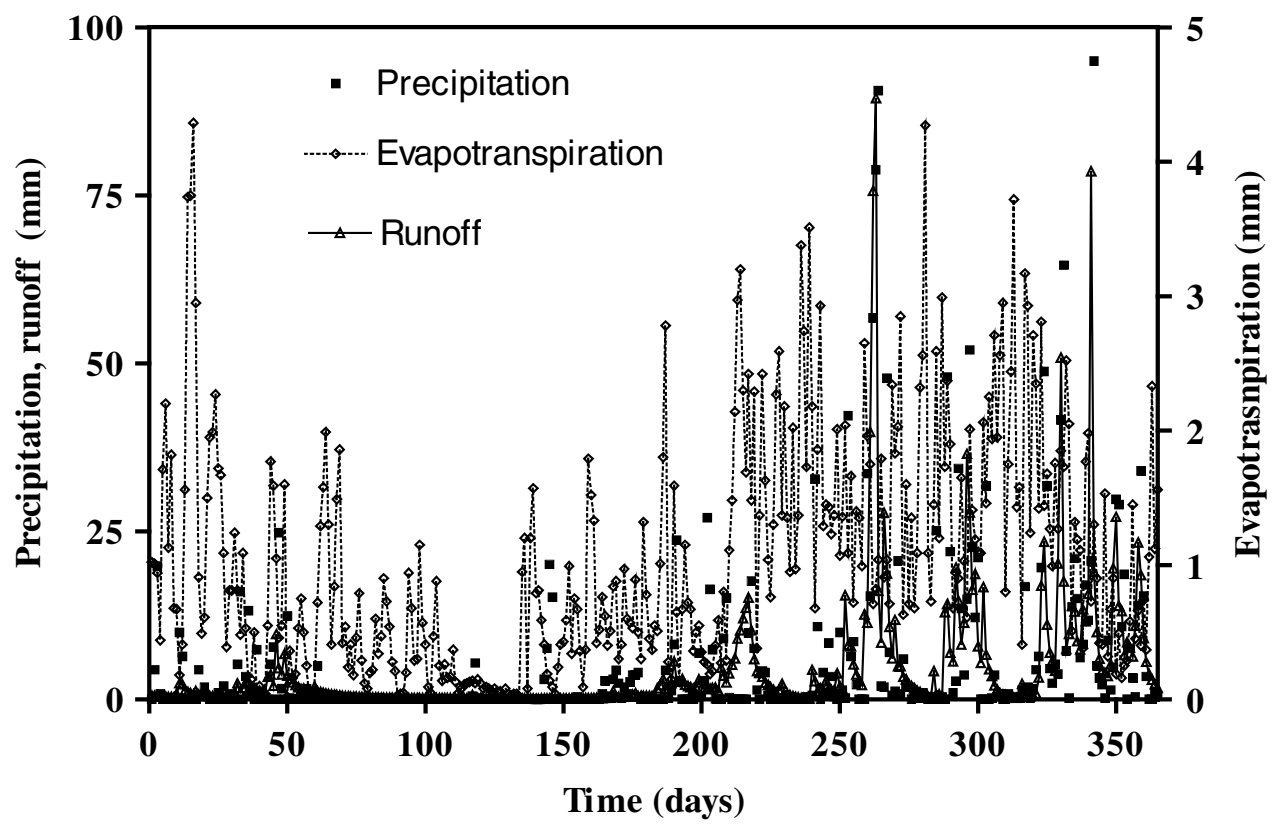

Fig. 5. Daily values of evapotranspiration and runoff predicted by BROOK90 (Ladové pleso catchment, 2001).

to observed data in these for small headwater basins (Tab. 9). The actual evapotranspiration in catchments (Tab. 10) varies from 78 to $99 \%$ of the potential calculated for the vaporizing water surface.

The calculated values are higher than the regional estimates in the High Tatra Mts reported by ToMLAIN (1985): mean annual evapotranspiration 250-300 $\mathrm{mm}$ by gradient of $-18 \mathrm{~mm} / 100 \mathrm{~m}$. MikLANEK \& Meszaros (1998) reported daily evapotranspiration in a small catchment $\left(23 \mathrm{~km}^{2}\right)$ of Jalovecká dolina valley (elevation up to $2100 \mathrm{~m}$ ) in April from 1-2 mm (north face) to 3-4 mm (south face). Those data are close to our results. However, the aim of our experiment was to contribute to better knowledge of water balance in high-elevated headwater basins above the timberline.

Runoff

From tracer experiments in 2000-2001, at the Ladové pleso 1 , the maximum decrease of tracer concentrations were observed in lower layers of the lake (TUREK, 2002). The residence time fluctuated from 32 to 313 days (by the weighted annual average of 136 days). The residence time in the Ladové pleso (Tab. 11). In comparison to the other investigated lakes, in the basin of the Ladové pleso, a relatively slow subsurface flow from the basin
Table 11. The residence time in Ladové pleso.

\begin{tabular}{lccc}
\hline Date & $\begin{array}{c}\text { Time since } \\
\text { application } \\
\text { (days) }\end{array}$ & $\begin{array}{c}\text { Dilution } \\
\left(\text { day }^{-1}\right)\end{array}$ & $\begin{array}{c}\text { Residence time } \\
\text { (days) }\end{array}$ \\
\hline $21 / 12 / 2000$ & 55 & 0.0185 & 54 \\
$25 / 04 / 2001$ & 125 & 0.0032 & 313 \\
$18 / 07 / 2001$ & 84 & 0.0193 & 52 \\
$27 / 10 / 2001$ & 101 & 0.0310 & 32 \\
Annual average & 365 & 0.0074 & 136 \\
\hline
\end{tabular}

into the lake dominates, streaming inflows are not developed, and outflow occurred only by the lake seepage. Therefore, the basin of the Ladové pleso seems to be suitable for application of precipitation-runoff models to study the runoff genesis.

The deterministic model Brook90 applied here seems to be an effective tool to study precipitationrunoff genesis in small headwater catchments. At the basin Ladové pleso, the predicted and observed water yield (Figs 5-6) show relatively good correlation:

Pearson $r=0.72\left(r_{\text {crit }}=0.66, n=365, P=0.05\right)$. The annual sum of actual evapotranspiration calculated 
Ladové Pleso: 1.10.2000-30.9.2001

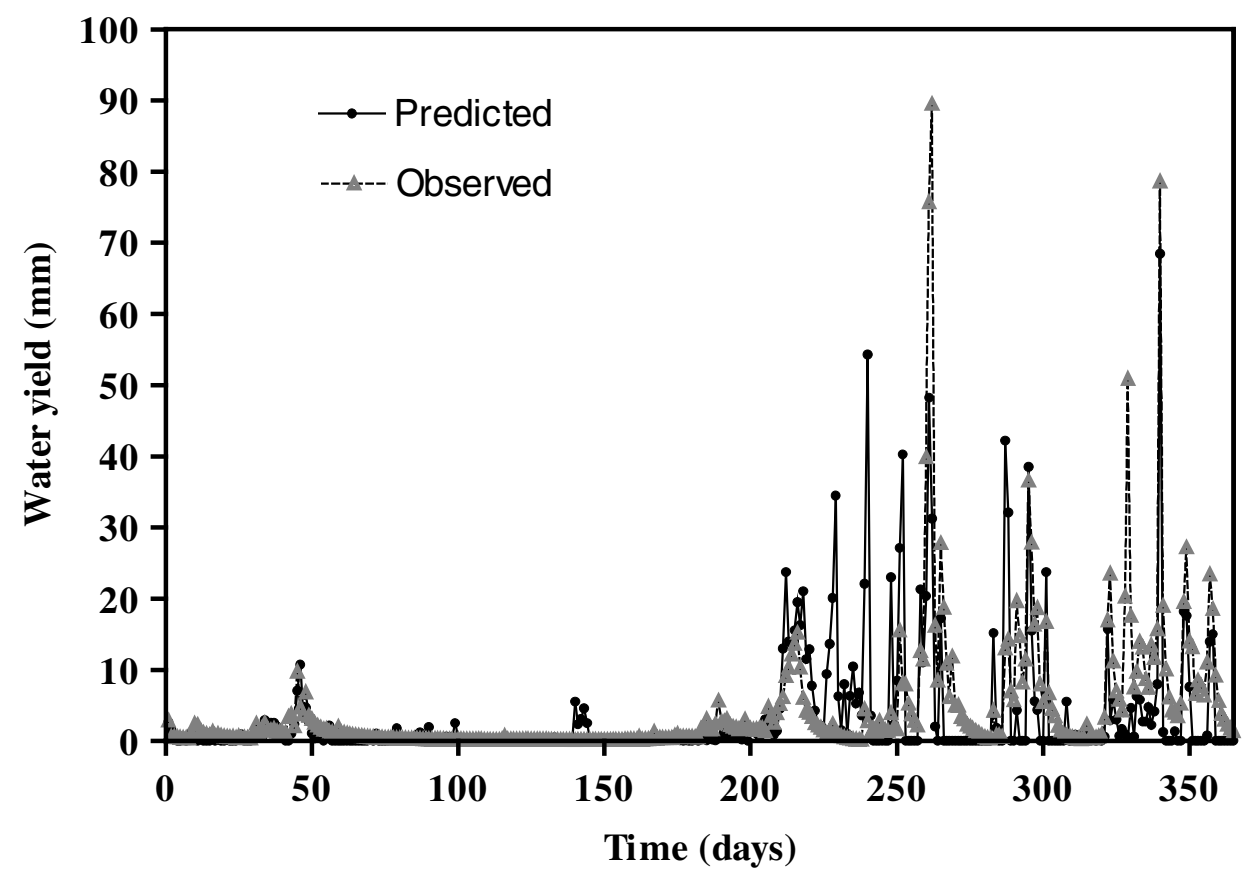

Fig. 6. Daily water yield of Ladové pleso basin: predicted by BROOK90 versus observed (calculated from the water balance of the lake).

by BROOK90 (352 $\mathrm{mm})$ also good corresponds to the value estimated by the approach of Penman (386 mm).

The data of watersheds registered in the standard hydrological network (Tab. 3) include lower elevations with different ecosystems (namely a high percentage of forest cover from 30 to $50 \%$ of the basin area). So, it is difficult to compare these data with water balance estimates of basins above the timberline. The low value of actual evapotranspiration $(E T=150 \mathrm{~mm})$ reported by VOLOŠČUK et al. (1994) for the catchment of Studený potok (Nad Starou Lesnou, $18.5 \mathrm{~km}^{2}, 30 \%$ forested) seems not to be realistic.

The empirical hydrological results show that hydrological processes are governed by the temperaturedependent regime of high mountain snowmelt. However, they also highlight major differences between both water yield and runoff genesis in the watersheds, which are caused by the differences in the morphologies of the lakes and their basins, in the soil-vegetation complex, and in runoff routing.

\section{Acknowledgements}

The research was supported by the European Union projects EMERGE (EVK1-CT-1999-00032) and EUROLIMPACS (GOCE-CT-2003-505540), project of the Grant Agency of the Czech Republic (103/04/0214, Water resources control in headwater catchments), and project of the Czech Ministry of Education (MSM 6840770002, Revitalisation of Landscape affected by anthropogenic changes).

\section{References}

Burroughs, W.J. 1991. Watching the Worlds Weather. Cambridge University Press, 196 pp.

Chow, V.T., Maidment, D.R. \& Mays, L.W. 1988. Applied Hydrology. McGraw-Hill, New York, 571 pp.

Dub, O. \& NĚMEC, J. 1969. Hydrologie [Hydrology]. SNTL, Praha, $379 \mathrm{pp}$

FEDERER, C.A. 1992. Brook 90: a simulation model for evaporation, soil water and streamflow. USDA Forest Service, Durham, New Hampshire, 106 pp.

Fott, J., PražÁková, M., Stuchlík, E. \& Stuchlíková, Z 1994. Acidification of lakes in Sumava (Bohemia) and in the High Tatra Mountains (Slovakia). Hydrobiologia 247: 37-47.

Gonzales, J. 2000. Monitoring cloud interception in a tropical montane cloud forest of the south-western Colombian Ands. Advances in Environmental Monitoring and Modelling 1 (1): $97-117$.

HAigh, M.J. \& KR̆EČEK, J. 2000. Environmental reconstruction in headwater areas. Kluwer, Dordrecht, $243 \mathrm{pp}$.

Hall, R.L., Calder, I.R., Rosier, P.T.W., Swaminath, M.H. \& Mumtaz, J. 1992. Measurements and modeling of interception loss from Eucalyptus plantation in Southern India, pp. 270-289. In: CALDER, I.R. et al. (eds) Growth and water use of forest plantations, John Wiley \& Sons, Chichester.

Henderson-Sellers, A. \& Robinson, P.J. 1989. Contemporary climatology. Longman House, Harlow, $439 \mathrm{pp}$.

HMU 1962. Atlas podnebí Československé republiky [Climate Atlas of Czechoslovakia]. Centre of Cartography, Prague, Czech Republic, 453 pp.

HMU 1968. Hydrologické poměry Československé republiky [Hydrological conditions of Czechoslovakia]. Hydro-meteorological Institute (HMU), Prague, Czech Republic, Volumes I-III, 1276 pp.

Kemel, M. 1972. Hydrologie [Hydrology]. Czech Technical University in Prague, Faculty of Civil Engineering, Prague, Czech Republic, 290 pp. 
Ǩ̌EČEK, J. \& RusNOK, J. 1993. Maharlu: hydrological model for mountain semiarid basins, pp. 234-241. In: AFrASIABIAN, A. \& FARHOODI, G. (eds) Water resources in karst with special emphasis on arid and semi arid zones, Iranian Ministry of Energy, Shiraz, Iran.

LAJCZAK, A. 1996. Hydrologia [Hydrology], pp. 169-196. In: Mirek, Z., Geowaciński, Z., Klimek, K. \& PiekošMirkowa H. (eds) Przyroda Tatrzańskiego Parku Narodowego [The nature in the High Tatras National Park], Zakopane-Kraków, Poland.

Linsley, R.K., Kohler, M.A. \& Paulhus, J.L.H. 1975. Hydrology for engineers. McGraw-Hill Kogakusha Ltd., Tokyo, $482 \mathrm{pp}$.

LJUNGGREN, E. 2002. Water balance estimates and modelling hydrological processes in a small Alpine catchment: the High Tatra Mountains, Slovakia. MSc. Thesis, Czech Technical University in Prague, Faculty of Civil Engineering, Prague, 35 pp.

LopATOVÁ, E. 2003. Prostorová a časová distribuce množství a chemizmu atmosférické depozice $\mathrm{v}$ alpinském pásmu Vysokých Tater [Spatial distribution and seasonal change of amount and chemistry of atmospheric deposition in alpine zone of the High Tatra Mountains]. MSc. Thesis, Faculty of Science, Charles University in Prague, Czech Republic, 67 pp.
Miklanek, P. \& Meszaros, I. 1998. Modelling of potential evapotranspiration in mountainous areas taking into account the terrain shadowing, pp. 54-57. In: TAPPEINER, U. (ed.) Hydrology, water resources and ecology of mountain areas, European Academy, Bolzano, Italy,

SHAw, E.M. 1991. Hydrology in practice. Chapman \& Hall, London, 539 pp.

Šporka, F., Livingstone, D.M., Stuchlík, E., Turek, J. \& GAlAs, J. 2006. Water temperatures and ice cover in lakes of the Tatra Mountains. Biologia, Bratislava 61, Supl. 18: S77-S90.

TOMLAIN, J. 1985. Mapping evapotranspiration on the territory of Slovakia for 1951-1980. Met. Bull. 38: 140-145.

TUREK, J. 2002. Hydrologický režim vysokohorských jezer na území Vysokých Tater [Hydrological regime of alpine lakes in the High Tatras]. MSc. Thesis, Faculty of Science, Charles University in Prague, Czech Republic, 80 pp.

Vološcuk, I. (ed.) 1994. Tatranský národný park [The Tatra National Park]. Gradus, Martin, Slovak Republic, 551 pp.

Received December 4, 2005 Accepted May 9, 2006 